\title{
Proteinase-activated receptors (version 2019.4) in the IUPHAR/BPS Guide to Pharmacology Database
}

Nigel Bunnett ${ }^{1}$, Kathryn DeFea ${ }^{2}$, Justin Hamilton ${ }^{1}$, Morley D. Hollenberg ${ }^{3}$, Rithwik Ramachandran ${ }^{4}$ and JoAnn Trejo 5

1. Monash University, Australia

2. University of California Riverside, USA

3. University of Calgary, Canada

4. University of Western Ontario, Canada

5. University of California San Diego, USA

\begin{abstract}
Proteinase-activated receptors (PARs, nomenclature as agreed by the NC-IUPHAR Subcommittee on Proteinase-activated Receptors [35]) are unique members of the GPCR superfamily activated by proteolytic cleavage of their amino terminal exodomains. Agonist proteinase-induced hydrolysis unmasks a tethered ligand $(\mathrm{TL})$ at the exposed amino terminus, which acts intramolecularly at the binding site in the body of the receptor to effect transmembrane signalling. TL sequences at human PAR1-4 are SFLLRN-NH ${ }_{2}$, SLIGKV-NH ${ }_{2}$, TFRGAP$\mathrm{NH}_{2}$ and GYPGQV-NH$H_{2}$, respectively. With the exception of PAR3, synthetic peptides with these sequences (as carboxyl terminal amides) are able to act as agonists at their respective receptors. Several proteinases, including neutrophil elastase, cathepsin $G$ and chymotrypsin can have inhibitory effects at PAR1 and PAR2 such that they cleave the exodomain of the receptor without inducing activation of Goq-coupled calcium signalling, thereby preventing activation by activating proteinases but not by agonist peptides. Neutrophil elastase (NE) cleavage of PAR1 and PAR2 can however activate MAP kinase signaling by exposing a TL that is different from the one revealed by trypsin [73]. PAR2 ectivation by NE regulates inflammation and pain responses $[101,65]$ and triggers mucin secretion from airway epithelial cells [102].
\end{abstract}

\section{Contents}

This is a citation summary for Proteinase-activated receptors in the Guide to Pharmacology database (GtoPdb). It exists purely as an adjunct to the database to facilitate the recognition of citations to and from the database by citation analyzers. Readers will almost certainly want to visit the relevant sections of the database which are given here under database links.

GtoPdb is an expert-driven guide to pharmacological targets and the substances that act on them. GtoPdb is a reference work which is most usefully represented as an on-line database. As in any publication this work should be appropriately cited, and the papers it cites should also be recognized. This document provides a citation for the relevant parts of the database, and also provides a reference list for the research cited by those parts.

Please note that the database version for the citations given in GtoPdb are to the most recent preceding version in which the family or its subfamilies and targets were substantially changed. The links below are to the current 
version. If you need to consult the cited version, rather than the most recent version, please contact the GtoPdb curators.

\section{Database links}

Proteinase-activated receptors

http://www.guidetopharmacology.org/GRAC/FamilyDisplayForward?familyld=59

Introduction to Proteinase-activated receptors

http://www.guidetopharmacology.org/GRAC/FamilyIntroductionForward?familyld=59

Receptors

PAR1

http://www.guidetopharmacology.org/GRAC/ObjectDisplayForward?objectld=347

PAR2

http://www.guidetopharmacology.org/GRAC/ObjectDisplayForward?objectld=348

PAR3

http://www.guidetopharmacology.org/GRAC/ObjectDisplayForward?objectld=349

PAR4

http://www.guidetopharmacology.org/GRAC/ObjectDisplayForward?objectld=350

\section{References}

1. Ahn HS, Foster C, Boykow G, Arik L, Smith-Torhan A, Hesk D and Chatterjee M. (1997) Binding of a thrombin receptor tethered ligand analogue to human platelet thrombin receptor. Mol. Pharmacol. 51: 3506 [PMID:9203642]

2. Al-Ani B, Saifeddine M, Kawabata A, Renaux B, Mokashi S and Hollenberg MD. (1999) Proteinaseactivated receptor 2 (PAR(2)): development of a ligand-binding assay correlating with activation of PAR(2) by PAR(1)- and PAR(2)-derived peptide ligands. J. Pharmacol. Exp. Ther. 290: 753-60 [PMID:10411588]

3. Almonte AG, Hamill CE, Chhatwal JP, Wingo TS, Barber JA, Lyuboslavsky PN, David Sweatt J, Ressler KJ, White DA and Traynelis SF. (2007) Learning and memory deficits in mice lacking protease activated receptor-1. Neurobiol Learn Mem 88: 295-304 [PMID:17544303]

4. Almonte AG, Qadri LH, Sultan FA, Watson JA, Mount DJ, Rumbaugh G and Sweatt JD. (2013) Proteaseactivated receptor-1 modulates hippocampal memory formation and synaptic plasticity. J. Neurochem. 124: 109-22 [PMID:23113835]

5. Amiable N, Martel-Pelletier J, Lussier B, Kwan Tat S, Pelletier JP and Boileau C. (2011) Proteinaseactivated receptor-2 gene disruption limits the effect of osteoarthritis on cartilage in mice: a novel target in joint degradation. J. Rheumatol. 38: 911-20 [PMID:21285164]

6. Andrade-Gordon P, Maryanoff BE, Derian CK, Zhang HC, Addo MF, Darrow AL, Eckardt AJ, Hoekstra WJ, McComsey DF and Oksenberg D et al.. (1999) Design, synthesis, and biological characterization of a peptide-mimetic antagonist for a tethered-ligand receptor. Proc. Natl. Acad. Sci. U.S.A. 96: 12257-62 [PMID:10535908]

7. Antoniak S, Owens 3rd AP, Baunacke M, Williams JC, Lee RD, Weithäuser A, Sheridan PA, Malz R, Luyendyk JP and Esserman DA et al.. (2013) PAR-1 contributes to the innate immune response during viral infection. J. Clin. Invest. 123: 1310-22 [PMID:23391721]

8. Aronovich A, Nur Y, Shezen E, Rosen C, Zlotnikov Klionsky Y, Milman I, Yarimi L, Hagin D, Rechavi G and Martinowitz $\mathrm{U}$ et al.. (2013) A novel role for factor VIII and thrombin/PAR1 in regulating hematopoiesis and its interplay with the bone structure. Blood 122: 2562-71 [PMID:23982175]

9. Atzori L, Lucattelli M, Scotton CJ, Laurent GJ, Bartalesi B, De Cunto G, Lunghi B, Chambers RC and Lungarella G. (2009) Absence of proteinase-activated receptor-1 signaling in mice confers protection from fMLP-induced goblet cell metaplasia. Am. J. Respir. Cell Mol. Biol. 41: 680-7 [PMID:19307611]

10. Austin KM, Covic L and Kuliopulos A. (2013) Matrix metalloproteases and PAR1 activation.Blood 121: 431-9 [PMID:23086754] 
11. Badeanlou L, Furlan-Freguia C, Yang G, Ruf W and Samad F. (2011) Tissue factor-protease-activated receptor 2 signaling promotes diet-induced obesity and adipose inflammation. Nat. Med. 17: 1490-7 [PMID:22019885]

12. Barry GD, Suen JY, Le GT, Cotterell A, Reid RC and Fairlie DP. (2010) Novel agonists and antagonists for human protease activated receptor 2. J. Med. Chem. 53: 7428-40 [PMID:20873792]

13. Blackhart BD, Emilsson K, Nguyen D, Teng W, Martelli AJ, Nystedt S, Sundelin J and Scarborough RM. (1996) Ligand cross-reactivity within the protease-activated receptor family. J. Biol. Chem. 271: 16466-71 [PMID:8663335]

14. Boitano S, Hoffman J, Flynn AN, Asiedu MN, Tillu DV, Zhang Z, Sherwood CL, Rivas CM, DeFea KA and Vagner J et al.. (2015) The novel PAR2 ligand C391 blocks multiple PAR2 signalling pathways in vitro and in vivo. Br. J. Pharmacol. 172: 4535-4545 [PMID:26140338]

15. Bourgognon JM, Schiavon E, Salah-Uddin H, Skrzypiec AE, Attwood BK, Shah RS, Patel SG, Mucha M, John Challiss RA and Forsythe ID et al.. (2013) Regulation of neuronal plasticity and fear by a dynamic change in PAR1-G protein coupling in the amygdala. Mol. Psychiatry 18: 1136-45 [PMID:23032873]

16. Burda JE, Radulovic M, Yoon H and Scarisbrick IA. (2013) Critical role for PAR1 in kallikrein 6-mediated oligodendrogliopathy. Glia 61: 1456-70 [PMID:23832758]

17. Bushell TJ, Cunningham MR, McIntosh KA, Moudio S and Plevin R. (2016) Protease-Activated Receptor 2: Are Common Functions in Glial and Immune Cells Linked to Inflammation-Related CNS Disorders? Curr Drug Targets 17: 1861-1870 [PMID:26648078]

18. Busso N, Frasnelli M, Feifel R, Cenni B, Steinhoff M, Hamilton J and So A. (2007) Evaluation of proteaseactivated receptor 2 in murine models of arthritis. Arthritis Rheum. 56: 101-7 [PMID:17195212]

19. Chackalamannil S, Wang Y, Greenlee WJ, Hu Z, Xia Y, Ahn HS, Boykow G, Hsieh Y, Palamanda J and Agans-Fantuzzi J et al.. (2008) Discovery of a novel, orally active himbacine-based thrombin receptor antagonist (SCH 530348) with potent antiplatelet activity. J. Med. Chem. 51: 3061-4 [PMID:18447380]

20. Cheng RKY, Fiez-Vandal C, Schlenker O, Edman K, Aggeler B, Brown DG, Brown GA, Cooke RM, Dumelin CE and Doré AS et al.. (2017) Structural insight into allosteric modulation of protease-activated receptor 2. Nature 545: 112-115 [PMID:28445455]

21. Cheng Y, Xi G, Jin H, Keep RF, Feng J and Hua Y. (2014) Thrombin-induced cerebral hemorrhage: role of protease-activated receptor-1. Trans/ Stroke Res 5: 472-5 [PMID:24323711]

22. Chung AW, Jurasz P, Hollenberg MD and Radomski MW. (2002) Mechanisms of action of proteinaseactivated receptor agonists on human platelets. Br. J. Pharmacol. 135: 1123-32 [PMID:11877318]

23. Cornelissen I, Palmer D, David T, Wilsbacher L, Concengco C, Conley P, Pandey A and Coughlin SR. (2010) Roles and interactions among protease-activated receptors and P2ry12 in hemostasis and thrombosis. Proc. Natl. Acad. Sci. U.S.A. 107: 18605-10 [PMID:20930120]

24. Cottrell GS, Amadesi S, Pikios S, Camerer E, Willardsen JA, Murphy BR, Caughey GH, Wolters PJ, Coughlin SR and Peterson A et al.. (2007) Protease-activated receptor 2, dipeptidyl peptidase I, and proteases mediate Clostridium difficile toxin A enteritis. Gastroenterology 132: 2422-37 [PMID:17570216]

25. Crilly A, Palmer H, Nickdel MB, Dunning L, Lockhart JC, Plevin R, McInnes IB and Ferrell WR. (2012) Immunomodulatory role of proteinase-activated receptor-2. Ann. Rheum. Dis. 71: 1559-66 [PMID:22563031]

26. Davidson CE, Asaduzzaman M, Arizmendi NG, Polley D, Wu Y, Gordon JR, Hollenberg MD, Cameron L and Vliagoftis H. (2013) Proteinase-activated receptor-2 activation participates in allergic sensitization to house dust mite allergens in a murine model. Clin. Exp. Allergy 43: 1274-85 [PMID:24152160]

27. de Boer JD, Van't Veer C, Stroo I, van der Meer AJ, de Vos AF, van der Zee JS, Roelofs JJ and van der Poll T. (2014) Protease-activated receptor-2 deficient mice have reduced house dust mite-evoked allergic lung inflammation. Innate Immun 20: 618-25 [PMID:24048772]

28. De Cunto G, Cardini S, Cirino G, Geppetti P, Lungarella G and Lucattelli M. (2011) Pulmonary hypertension in smoking mice over-expressing protease-activated receptor-2. Eur. Respir. J. 37: 823-34 [PMID:20693251]

29. Edelstein LC, Simon LM, Lindsay CR, Kong X, Teruel-Montoya R, Tourdot BE, Chen ES, Ma L, Coughlin 
S and Nieman M et al.. (2014) Common variants in the human platelet PAR4 thrombin receptor alter platelet function and differ by race. Blood 124: 3450-8 [PMID:25293779]

30. Gardell LR, Ma JN, Seitzberg JG, Knapp AE, Schiffer HH, Tabatabaei A, Davis CN, Owens M, Clemons B and Wong KK et al.. (2008) Identification and characterization of novel small-molecule protease-activated receptor 2 agonists. J. Pharmacol. Exp. Ther. 327: 799-808 [PMID:18768780]

31. Georgy SR, Pagel CN, Ghasem-Zadeh A, Zebaze RM, Pike RN, Sims NA and Mackie EJ. (2012) Proteinase-activated receptor-2 is required for normal osteoblast and osteoclast differentiation during skeletal growth and repair. Bone 50: 704-12 [PMID:22173052]

32. Guo H, Liu D, Gelbard H, Cheng T, Insalaco R, Fernández JA, Griffin JH and Zlokovic BV. (2004) Activated protein $C$ prevents neuronal apoptosis via protease activated receptors 1 and 3. Neuron 41: 56372 [PMID:14980205]

33. Hamill CE, Mannaioni G, Lyuboslavsky P, Sastre AA and Traynelis SF. (2009) Protease-activated receptor 1-dependent neuronal damage involves NMDA receptor function. Exp. Neurol. 217: 136-46 [PMID:19416668]

34. Hamilton JR, Cornelissen I and Coughlin SR. (2004) Impaired hemostasis and protection against thrombosis in protease-activated receptor 4-deficient mice is due to lack of thrombin signaling in platelets. J. Thromb. Haemost. 2: 1429-35 [PMID:15304051]

35. Hollenberg MD and Compton SJ. (2002) International Union of Pharmacology. XXVIII. Proteinaseactivated receptors. Pharmacol. Rev. 54: 203-17 [PMID:12037136]

36. Hollenberg MD, Renaux B, Hyun E, Houle S, Vergnolle N, Saifeddine M and Ramachandran R. (2008) Derivatized 2-furoyI-LIGRLO-amide, a versatile and selective probe for proteinase-activated receptor 2: binding and visualization. J. Pharmacol. Exp. Ther. 326: 453-62 [PMID:18477767]

37. Holzhausen M, Spolidorio LC, Ellen RP, Jobin MC, Steinhoff M, Andrade-Gordon P and Vergnolle N. (2006) Protease-activated receptor-2 activation: a major role in the pathogenesis of Porphyromonas gingivalis infection. Am. J. Pathol. 168: 1189-99 [PMID:16565494]

38. Howell DC, Johns RH, Lasky JA, Shan B, Scotton CJ, Laurent GJ and Chambers RC. (2005) Absence of proteinase-activated receptor-1 signaling affords protection from bleomycin-induced lung inflammation and fibrosis. Am. J. Pathol. 166: 1353-65 [PMID:15855637]

39. Jenkins RG, Su X, Su G, Scotton CJ, Camerer E, Laurent GJ, Davis GE, Chambers RC, Matthay MA and Sheppard D. (2006) Ligation of protease-activated receptor 1 enhances alpha(v)beta6 integrin-dependent TGF-beta activation and promotes acute lung injury. J. Clin. Invest. 116: 1606-14 [PMID:16710477]

40. Jin G, Hayashi T, Kawagoe J, Takizawa T, Nagata T, Nagano I, Syoji M and Abe K. (2005) Deficiency of PAR-2 gene increases acute focal ischemic brain injury. J. Cereb. Blood Flow Metab. 25: 302-13 [PMID:15647743]

41. Junge CE, Sugawara T, Mannaioni G, Alagarsamy S, Conn PJ, Brat DJ, Chan PH and Traynelis SF. (2003) The contribution of protease-activated receptor 1 to neuronal damage caused by transient focal cerebral ischemia. Proc. Natl. Acad. Sci. U.S.A. 100: 13019-24 [PMID:14559973]

42. Kanke $T$, Ishiwata $H$, Kabeya M, Saka M, Doi T, Hattori Y, Kawabata A and Plevin R. (2005) Binding of a highly potent protease-activated receptor-2 (PAR2) activating peptide, [3H]2-furoyl-LIGRL-NH2, to human PAR2. Br. J. Pharmacol. 145: 255-63 [PMID:15765104]

43. Kawabata A, Matsunami M, Tsutsumi M, Ishiki T, Fukushima O, Sekiguchi F, Kawao N, Minami T, Kanke T and Saito N. (2006) Suppression of pancreatitis-related allodynia/hyperalgesia by proteinase-activated receptor-2 in mice. Br. J. Pharmacol. 148: 54-60 [PMID:16520745]

44. Kawabata A, Saifeddine M, AI-Ani B, Leblond L and Hollenberg MD. (1999) Evaluation of proteinaseactivated receptor-1 (PAR1) agonists and antagonists using a cultured cell receptor desensitization assay: activation of PAR2 by PAR1-targeted ligands. J. Pharmacol. Exp. Ther. 288: 358-70 [PMID:9862790]

45. Kawagoe J, Takizawa T, Matsumoto J, Tamiya M, Meek SE, Smith AJ, Hunter GD, Plevin R, Saito N and Kanke $T$ et al.. (2002) Effect of protease-activated receptor-2 deficiency on allergic dermatitis in the mouse ear. Jpn. J. Pharmacol. 88: 77-84 [PMID:11859856]

46. Khoufache K, LeBouder F, Morello E, Laurent F, Riffault S, Andrade-Gordon P, Boullier S, Rousset P, 
Vergnolle N and Riteau B. (2009) Protective role for protease-activated receptor-2 against influenza virus pathogenesis via an IFN-gamma-dependent pathway. J. Immunol. 182: 7795-802 [PMID:19494303]

47. Knight V, Tchongue J, Lourensz D, Tipping P and Sievert W. (2012) Protease-activated receptor 2 promotes experimental liver fibrosis in mice and activates human hepatic stellate cells. Hepatology 55 : 879-87 [PMID:22095855]

48. Kogushi M, Matsuoka T, Kawata T, Kuramochi H, Kawaguchi S, Murakami K, Hiyoshi H, Suzuki S, Kawahara T and Kajiwara A et al.. (2011) The novel and orally active thrombin receptor antagonist E5555 (Atopaxar) inhibits arterial thrombosis without affecting bleeding time in guinea pigs. Eur. J. Pharmacol. 657: 131-7 [PMID:21300059]

49. Lam DK and Schmidt BL. (2010) Serine proteases and protease-activated receptor 2-dependent allodynia: a novel cancer pain pathway. Pain 149: 263-72 [PMID:20189717]

50. Lee H, Sturgeon SA, Jackson SP and Hamilton JR. (2012) The contribution of thrombin-induced platelet activation to thrombus growth is diminished under pathological blood shear conditions. Thromb. Haemost. 107: 328-37 [PMID:22187047]

51. Lee JH, Kim KW, Gee HY, Lee J, Lee KH, Park HS, Kim SH, Kim SW, Kim MN and Kim KEet al.. (2011) A synonymous variation in protease-activated receptor-2 is associated with atopy in Korean children. $J$. Allergy Clin. Immunol. 128: 1326-1334.e3 [PMID:21839502]

52. Lee MC and Huang SC. (2008) Proteinase-activated receptor-1 (PAR(1)) and PAR(2) but not PAR(4) mediate contraction in human and guinea-pig gallbladders. Neurogastroenterol. Motil. 20: 385-91 [PMID:18179608]

53. Lewkowich IP, Day SB, Ledford JR, Zhou P, Dienger K, Wills-Karp M and Page K. (2011) Proteaseactivated receptor 2 activation of myeloid dendritic cells regulates allergic airway inflammation. Respir. Res. 12: 122 [PMID:21936897]

54. Li M, Yang X, Zhang Y, Chen L, Lu H, Li X, Yin L and Zhi X. (2015) Activation of protease-activated receptor-2 is associated with increased expression of inflammatory factors in the adipose tissues of obese mice. Mol Med Rep 12: 6227-34 [PMID:26252901]

55. Lindner JR, Kahn ML, Coughlin SR, Sambrano GR, Schauble E, Bernstein D, Foy D, Hafezi-Moghadam A and Ley K. (2000) Delayed onset of inflammation in protease-activated receptor-2-deficient mice. J. Immunol. 165: 6504-10 [PMID:11086091]

56. Liu S, Liu YP, Yue DM and Liu GJ. (2014) Protease-activated receptor 2 in dorsal root ganglion contributes to peripheral sensitization of bone cancer pain. Eur J Pain 18: 326-37 [PMID:23893658]

57. Liu Y, Ji W, Yin Y, Fan L, Zhang J, Yun H, Wang N, Li Q, Wei Z and Ouyang Det al.. (2009) The effects of splicing variant of PXR PAR-2 on CYP3A4 and MDR1 mRNA expressions. Clin. Chim. Acta 403: 142-4 [PMID:19232333]

58. Luyendyk JP, Mackman N and Sullivan BP. (2011) Role of fibrinogen and protease-activated receptors in acute xenobiotic-induced cholestatic liver injury. Toxicol. Sci. 119: 233-43 [PMID:20974703]

59. Mao Y, Zhang M, Tuma RF and Kunapuli SP. (2010) Deficiency of PAR4 attenuates cerebral ischemia/reperfusion injury in mice. J. Cereb. Blood Flow Metab. 30: 1044-52 [PMID:20087365]

60. Matej R, Olejar T, Janouskova $O$ and Holada K. (2012) Deletion of protease-activated receptor 2 prolongs survival of scrapie-inoculated mice. J. Gen. Virol. 93: 2057-61 [PMID:22694901]

61. McGuire JJ, Saifeddine M, Triggle CR, Sun K and Hollenberg MD. (2004) 2-furoyl-LIGRLO-amide: a potent and selective proteinase-activated receptor 2 agonist. J. Pharmacol. Exp. Ther. 309: 1124-31 [PMID:14976230]

62. McGuire JJ, Van Vliet BN and Halfyard SJ. (2008) Blood pressures, heart rate and locomotor activity during salt loading and angiotensin II infusion in protease-activated receptor 2 (PAR2) knockout mice. BMC Physiol. 8: 20 [PMID:18939990]

63. Moussa L, Apostolopoulos J, Davenport P, Tchongue J and Tipping PG. (2007) Protease-activated receptor-2 augments experimental crescentic glomerulonephritis. Am. J. Pathol. 171: 800-8 [PMID:17640968]

64. Muehlschlegel JD, Perry TE, Liu KY, Fox AA, Smith SA, Lichtner P, Collard CD, Shernan SK, Hartwig JH 
and Body SC et al.. (2012) Polymorphism in the protease-activated receptor-4 gene region associates with platelet activation and perioperative myocardial injury. Am. J. Hematol. 87: 161-6 [PMID:22228373]

65. Muley MM, Reid AR, Botz B, Bölcskei K, Helyes Z and McDougall JJ. (2016) Neutrophil elastase induces inflammation and pain in mouse knee joints via activation of proteinase-activated receptor-2. Br. J. Pharmacol. 173: 766-77 [PMID:26140667]

66. Nagai T, Ito M, Nakamichi N, Mizoguchi H, Kamei H, Fukakusa A, Nabeshima T, Takuma $K$ and Yamada K. (2006) The rewards of nicotine: regulation by tissue plasminogen activator-plasmin system through protease activated receptor-1. J. Neurosci. 26: 12374-83 [PMID:17122062]

67. Nagai T, Nabeshima T and Yamada K. (2008) Basic and translational research on proteinase-activated receptors: regulation of nicotine reward by the tissue plasminogen activator (TPA) - plasmin system via proteinase-activated receptor 1. J. Pharmacol. Sci. 108: 408-14 [PMID:19098386]

68. Noorbakhsh F, Tsutsui S, Vergnolle N, Boven LA, Shariat N, Vodjgani M, Warren KG, Andrade-Gordon P, Hollenberg MD and Power C. (2006) Proteinase-activated receptor 2 modulates neuroinflammation in experimental autoimmune encephalomyelitis and multiple sclerosis. J. Exp. Med. 203: 425-35 [PMID:16476770]

69. Olejar T, Vetvicka D, Zadinova M, Pouckova P, Kukal J, Jezek P and Matej R. (2014) Dual role of host Par2 in a murine model of spontaneous metastatic B16 melanoma. Anticancer Res. 34: 3511-5 [PMID:24982362]

70. Page K, Ledford JR, Zhou P, Dienger K and Wills-Karp M. (2010) Mucosal sensitization to German cockroach involves protease-activated receptor-2. Respir. Res. 11: 62 [PMID:20497568]

71. Patel YM, Lordkipanidzé M, Lowe GC, Nisar SP, Garner K, Stockley J, Daly ME, Mitchell M, Watson SP and Austin SK et al.. (2014) A novel mutation in the P2Y12 receptor and a function-reducing polymorphism in protease-activated receptor 1 in a patient with chronic bleeding. J. Thromb. Haemost. 12: 716-25 [PMID:24612435]

72. Rajput PS, Lyden PD, Chen B, Lamb JA, Pereira B, Lamb A, Zhao L, Lei IF and Bai J. (2014) Protease activated receptor-1 mediates cytotoxicity during ischemia using in vivo and in vitro models. Neuroscience 281: 229-40 [PMID:25261684]

73. Ramachandran R, Noorbakhsh F, Defea K and Hollenberg MD. (2012) Targeting proteinase-activated receptors: therapeutic potential and challenges. Nat Rev Drug Discov 11: 69-86 [PMID:22212680]

74. Rullier A, Gillibert-Duplantier J, Costet P, Cubel G, Haurie V, Petibois C, Taras D, Dugot-Senant N, Deleris $G$ and Bioulac-Sage P et al.. (2008) Protease-activated receptor 1 knockout reduces experimentally induced liver fibrosis. Am. J. Physiol. Gastrointest. Liver Physiol. 294: G226-35 [PMID:17962354]

75. Sambrano GR, Weiss EJ, Zheng YW, Huang W and Coughlin SR. (2001) Role of thrombin signalling in platelets in haemostasis and thrombosis. Nature 413: 74-8 [PMID:11544528]

76. Schaffner F, Versteeg HH, Schillert A, Yokota N, Petersen LC, Mueller BM and Ruf W. (2010) Cooperation of tissue factor cytoplasmic domain and PAR2 signaling in breast cancer development. Blood 116: 6106-13 [PMID:20861457]

77. Schouten M, van't Veer C, Roelofs JJ, Levi M and van der Poll T. (2012) Protease-activated receptor-1 impairs host defense in murine pneumococcal pneumonia: a controlled laboratory study. Crit Care 16: R238 [PMID:23270594]

78. Seeliger S, Derian CK, Vergnolle N, Bunnett NW, Nawroth R, Schmelz M, Von Der Weid PY, Buddenkotte J, Sunderkötter $C$ and Metze D et al.. (2003) Proinflammatory role of proteinase-activated receptor-2 in humans and mice during cutaneous inflammation in vivo. FASEB J. 17: 1871-85 [PMID:14519665]

79. Seitzberg JG, Knapp AE, Lund BW, Mandrup Bertozzi S, Currier EA, Ma JN, Sherbukhin V, Burstein ES and Olsson R. (2008) Discovery of potent and selective small-molecule PAR-2 agonists. J. Med. Chem. 51: 5490-3 [PMID:18720984]

80. Sevastos J, Kennedy SE, Davis DR, Sam M, Peake PW, Charlesworth JA, Mackman N and Erlich JH. (2007) Tissue factor deficiency and PAR-1 deficiency are protective against renal ischemia reperfusion injury. Blood 109: 577-83 [PMID:16990608]

81. Sevigny LM, Zhang P, Bohm A, Lazarides K, Perides G, Covic L and Kuliopulos A. (2011) Interdicting 
protease-activated receptor-2-driven inflammation with cell-penetrating pepducins. Proc. Natl. Acad. Sci. U.S.A. 108: 8491-6 [PMID:21536878]

82. Singh VP, Bhagat L, Navina S, Sharif R, Dawra RK and Saluja AK. (2007) Protease-activated receptor-2 protects against pancreatitis by stimulating exocrine secretion. Gut 56: 958-64 [PMID:17114298]

83. Smith SM, Judge HM, Peters G, Armstrong M, Dupont A, Gaussem P and Storey RF. (2005) PAR-1 genotype influences platelet aggregation and procoagulant responses in patients with coronary artery disease prior to and during clopidogrel therapy. Platelets 16: 340-5 [PMID:16194864]

84. Strompfová V, Lauková A and Cilik D. (2013) Synbiotic administration of canine-derived strain Lactobacillus fermentum CCM 7421 and inulin to healthy dogs. Can. J. Microbiol. 59: 347-52 [PMID:23647348]

85. Suen JY, Barry GD, Lohman RJ, Halili MA, Cotterell AJ, Le GT and Fairlie DP. (2012) Modulating human proteinase activated receptor 2 with a novel antagonist (GB88) and agonist (GB110). Br. J. Pharmacol. 165: 1413-23 [PMID:21806599]

86. Takizawa T, Tamiya M, Hara T, Matsumoto J, Saito N, Kanke T, Kawagoe J and Hattori Y. (2005) Abrogation of bronchial eosinophilic inflammation and attenuated eotaxin content in protease-activated receptor 2-deficient mice. J. Pharmacol. Sci. 98: 99-102 [PMID:15879675]

87. Towstyka NY, Shiromizu CM, Keitelman I, Sabbione F, Salamone GV, Geffner JR, Trevani AS and Jancic CC. (2018) Modulation of $\gamma \delta$ T-cell activation by neutrophil elastase. Immunology 153: 225-237 [PMID:28888033]

88. Uusitalo-Jarvinen H, Kurokawa T, Mueller BM, Andrade-Gordon P, Friedlander M and Ruf W. (2007) Role of protease activated receptor 1 and 2 signaling in hypoxia-induced angiogenesis. Arterioscler. Thromb. Vasc. Biol. 27: 1456-62 [PMID:17363687]

89. Versteeg HH, Schaffner F, Kerver M, Ellies LG, Andrade-Gordon P, Mueller BM and Ruf W. (2008) Protease-activated receptor (PAR) 2, but not PAR1, signaling promotes the development of mammary adenocarcinoma in polyoma middle T mice. Cancer Res. 68: 7219-27 [PMID:18757438]

90. Wang J, Jin H, Hua Y, Keep RF and Xi G. (2012) Role of protease-activated receptor-1 in brain injury after experimental global cerebral ischemia. Stroke 43: 2476-82 [PMID:22811450]

91. Wang Y, Zhao Z, Chow N, Ali T, Griffin JH and Zlokovic BV. (2013) Activated protein C analog promotes neurogenesis and improves neurological outcome after focal ischemic stroke in mice via protease activated receptor 1. Brain Res. 1507: 97-104 [PMID:23438513]

92. Wee JL, Chionh YT, Ng GZ, Harbour SN, Allison C, Pagel CN, Mackie EJ, Mitchell HM, Ferrero RL and Sutton P. (2010) Protease-activated receptor-1 down-regulates the murine inflammatory and humoral response to Helicobacter pylori. Gastroenterology 138: 573-82 [PMID:19706295]

93. Weiss EJ, Hamilton JR, Lease KE and Coughlin SR. (2002) Protection against thrombosis in mice lacking PAR3. Blood 100: 3240-4 [PMID:12384423]

94. Weithauser A, Bobbert P, Antoniak S, Böhm A, Rauch BH, Klingel K, Savvatis K, Kroemer HK, Tschope C and Stroux A et al.. (2013) Protease-activated receptor-2 regulates the innate immune response to viral infection in a coxsackievirus B3-induced myocarditis. J. Am. Coll. Cardiol. 62: 1737-45 [PMID:23871888]

95. Wen W, Young SE, Duvernay MT, Schulte ML, Nance KD, Melancon BJ, Engers J, Locuson 2nd CW, Wood MR and Daniels JS et al.. (2014) Substituted indoles as selective protease activated receptor 4 (PAR-4) antagonists: Discovery and SAR of ML354. Bioorg. Med. Chem. Lett. 24: 4708-13 [PMID:25176330]

96. Wong DM, Tam V, Lam R, Walsh KA, Tatarczuch L, Pagel CN, Reynolds EC, O'Brien-Simpson NM, Mackie EJ and Pike RN. (2010) Protease-activated receptor 2 has pivotal roles in cellular mechanisms involved in experimental periodontitis. Infect. Immun. 78: 629-38 [PMID:19933835]

97. Xie Q, Xi G, Gong Y, Keep R, Muraszko K and Hua Y. (2013) Protease activated receptor-1 and brain edema formation in glioma models. Acta Neurochir. Suppl. 118: 191-4 [PMID:23564130]

98. Xue M, Chan YK, Shen K, Dervish S, March L, Sambrook PN and Jackson CJ. (2012) Protease-activated receptor 2, rather than protease-activated receptor 1, contributes to the aggressive properties of synovial fibroblasts in rheumatoid arthritis. Arthritis Rheum. 64: 88-98 [PMID:21905006] 
99. Yau MK, Suen JY, Xu W, Lim J, Liu L, Adams MN, He Y, Hooper JD, Reid RC and Fairlie DP. (2016) Potent Small Agonists of Protease Activated Receptor 2. ACS Med Chem Lett 7: 105-10 [PMID:26819675]

100. Zhang C, Srinivasan Y, Arlow DH, Fung JJ, Palmer D, Zheng Y, Green HF, Pandey A, Dror RO and Shaw DE et al.. (2012) High-resolution crystal structure of human protease-activated receptor 1.Nature 492: 387-92 [PMID:23222541]

101. Zhao P, Lieu T, Barlow N, Sostegni S, Haerteis S, Korbmacher C, Liedtke W, Jimenez-Vargas NN, Vanner SJ and Bunnett NW. (2015) Neutrophil Elastase Activates Protease-activated Receptor-2 (PAR2) and Transient Receptor Potential Vanilloid 4 (TRPV4) to Cause Inflammation and Pain. J. Biol. Chem. 290: 13875-87 [PMID:25878251]

102. Zhou J, Perelman JM, Kolosov VP and Zhou X. (2013) Neutrophil elastase induces MUC5AC secretion via protease-activated receptor 2. Mol. Cell. Biochem. 377: 75-85 [PMID:23392769]

103. Zhou QB, Duan CZ, Jia Q, Liu P and Li LY. (2014) Baicalin attenuates focal cerebral ischemic reperfusion injury by inhibition of protease-activated receptor-1 and apoptosis. Chin J Integr Med 20: 116-22 [PMID:23504578] 